\title{
The Shaping Of Cultural Knowledge In South African Translation*
}

Jacobus A. Naudé

Afroasiatic Studies, Sign Language and Language Practice, University of the Free State, P.O. Box 339, Bloemfontein 9300, South Africa

E-mail: naudej.hum@mail.uovs.ac.za

\section{Introduction}

Recent translation scholarship has demonstrated a growing emphasis on the collective control or shaping of cultural knowledge. This trend is particularly evident in terms of the role of ideology in the construction and maintenance of cultural knowledge (Katan 1999).

The objective of this paper is to illustrate how cultural knowledge is being controlled, shaped and constructed in South African translation. This paper, which constitutes the second of a series of three, also provides a sequel to the first paper on the theoretical development in translation studies. Whereas the first paper, which was written in 2001 (Naudé 2005), focused on the cultural turn in translation studies pertaining to the South African context, the forthcoming third paper will deal primarily with globalisation and South African translation. Collectively, the three papers will constitute a report on a research project at the University of the Free State which is nearing completion and in which approximately ten master students have been involved. The project aims to provide a description of existing translations, as well as translations performed by the students into English, Southern Sotho, Xhosa and Zulu (see Bambelo (2003), Danso (2002), Geldenhuys (2004), Hlongwane (2000), Leeto, (forthcoming), Lötter (2001), Makutoane (2003), Mlonyeni (2003), Mpoba (2001), and Mweza (forthcoming)). The project analysis falls within the 
framework of descriptive translation studies (DTS), with a view to determining the strategies of cultural transmission: how cultural knowledge is controlled, shaped and constructed by translations.

This paper has been organised as follows: Section 2 focuses on the characterisation of the concepts that are used for the analyses in Section 4. The analytical framework is depicted in Section 3, followed by an analysis of a selection of texts in Section 4 .

\section{The cultural turn in translation studies}

The dawn of a new millennium saw the emergence of translation studies carried out by an international network of scholarly communities engaged in scholarly debate across conceptual and disciplinary divisions (Venuti 2000:1). Since South Africa forms an integral part of this network (Beukes 1994, Walker et al. 1995, Kruger 2000), the developments within Translation Studies are also applicable to the South African context.

Linguistic-based theories (see Fawcett 1997) dominated translation studies until the cultural turn at the beginning of the 1980s. In terms of these theories, equivalence was the prevailing concern and yardstick/criterion against which translators were to judge their translations. Unfortunately, owing to linguistic and cultural differences between languages, translations inevitably fell short of the equivalence ideal (Heylen 1993:2). The principal shortcoming of prescriptive/normative translation theories also soon became evident: these theories lacked the necessary sensitivity to the socio-cultural conditions under which translations were produced in order to comply with the requirements of acts of communication in the receiving culture (Bassnett-McGuire 1991 [1980]; Bassnett \& Lefevere 1990). Thus, the realisation that translations can never be produced in a vacuum, divorced from time and culture, and the desire to explain the time-related and culturebound criteria at play, resulted in a shift away from a normative and prescriptive methodology (compare Hermans 1985). This trend was conspicuous from the early eighties on and can be related to the linguistic turn from an ahistorical and apolitical approach to language, towards a critical approach (Kress \& Hodge 1979, Fairclough 1989). It should furthermore be associated 
with the influence of semiotics, especially as found in the work of Roland Barthes, Mikhail Bakhtin and Valentin Voloshinov.

The move from translation as text, to translation as culture and politics, has been termed by Mary Snell-Hornby (1990:79-86) as the cultural turn. Bassnett and Lefevere (1990:11) consider this to be a metaphor for the cultural move beyond language in order to focus on the interaction between translation and culture, as well as on the way in which culture impacts on and constrains translation, and subsequently to focus also on the much broader issues of context, history and convention. This approach is inclusive of studies on changing standards in translation over time; the power exercised in and on the publishing industry in pursuit of specific ideologies; feminist writing and translation; translation as appropriation; translation and colonisation; and translation as rewriting, including film rewrites (Munday 2001:127).

Nord (1997:135) observed that after the changes in South Africa in the early 1990s, translation conventions were drastically affected by the increasing demand for translations, often entailing translations into languages which lacked the required terminological expansion. Added to this, adaptation and reformulation skills traditionally did not form part of translation programmes, as they were not considered compatible with the convention of mirror-image translation based on equivalence (Beukes 1994, Walker et al. 1995:105). In contrast, 'accessibility' has now become the buzzword, along with communication to the broadest possible audience, including those with limited levels of literacy. African-language translators, in particular, are therefore being trained to produce texts that are accessible to every level of society, even if this entails extensive rewriting of texts to ensure that they are understood by all recipients (Walker et al. 1995:102).

In the process two approaches to translation, the functionalist and the descriptive, developed independently though simultaneously (Naudé 2002:44-69). Both view translation as a new communicative act that is aimed at serving a purpose for the target culture, even if this results in differences from the source text. In the case of the functionalist approach, the intended function (skopos) of the target text, and not the function of the source text, determines the translation methods and strategies (Reiss \& Vermeer 1984). The function of the translation in the target 
culture is determinative in the decision as to which aspects of the source text should be transferred to the translation (Nord 1991:6). The descriptive approach originated in the 1970s with Even-Zohar's polysystem theory and created the impetus for the study of translation to move in the direction of an investigation of the position of translated literature as a whole vis-à-vis the historical and literary systems of the target culture. As a key constituent of many descriptive approaches, such investigative study encouraged researchers to ask what translation did in specific cultural settings (see Hermans 1999). In other words, the theorists attempted to account not only for textual strategies in the translated text, but also for the way in which the translation functioned in the target cultural and literary system (see Even-Zohar 1990 and Toury 1978/2000, 1995).

Bassnett and Lefevere (1990:4), working originally from within systems theory, dismissed the painstaking comparisons that were made between original texts and translations when the text was not being considered in its cultural environment. Instead, they examined translation as rewriting, while also taking the ideological tensions around the text into account. Furthermore, it should be noted that culturally orientated research stemmed from the influence of poststructuralism and emphasised the social and historical differences of translation. Perhaps the most significant of these critical syntheses - for post-apartheid South Africa - should be linked to postcolonial translation theory (Dimitriu 2002:v).

Arising from cultural anthropology in the late 1980s and early 1990s, postcolonial translation theory is based on the premise that translation has often served as an important imperialist tool in the colonisation of peoples, the survival of colonial attitudes in the translation marketplace, and in the decolonising of the mind (Robinson 1997): Europe was perceived as the original with the colonies as copies or translations of the original (Bassnett \& Trivedi 1999:4). Momentous trends in postcolonial studies were set by the study of globalisation, tribalisation and cultural identities. Globalisation, or the worldwide tendency towards standardisation, has provided a predictable, commercially homogeneous, global network linked by technology, ecology, communications and commerce (Crystal 2003). Linguistic retribalisation, in turn, refers to the at times extremely violent experiences of rediscovery of the own communal cultural heritage by people of particular 
language and culture groups (Snell-Hornby 2000). Situated between these two extremes is the concept of cultural identity that indicates a community's awareness of and pride in its own unmistakable features and its sense of belonging. The assumption is that such a community can live in harmony and can communicate with other communities around the world. For translation purposes, the implication thereof is that cultural words and concepts are utilised in the target text (i.e., the technique of foreignisation is applied) to allow for the clear demarcation of each cultural group. The terms resistancy and resistance, as used by Venuti (1995), refer to the strategy of translating a literary text in such a way that it retains something of its foreignness. This is also referred to as a resistive approach to translation (Wallmach 2000). Such an approach challenges the assumption that an acceptable translation is only produced when a translation reads fluently and idiomatically and is so transparent in reflecting the source text author's intention in the target language, that the translation could be mistaken for an original text. In this regard it is important to note Derrida's (2001) questioning of what he referred to as 'relevant translation'. Derrida called attention not only to the ethnocentric violence of relevant translation, but also to the simultaneous mystification of that violence through language that is seemingly transparent because it is univocal and idiomatic. In practice, following a resistive approach to translation may involve either choosing to translate a text that challenges the contemporary canon of foreign literature in the target language, or using unidiomatic expressions and other linguistically and culturally alienating features in the translated text in order to create an impression of foreignness, thereby providing readers of the translation with an alien reading experience.

The abovementioned developments have led to the quest for the 'opening up' of foreign culture. This may be achieved by means of interlingual translation. In this context translation is regarded as the reproduction of culture, since the act of translating literary texts, in particular, involves transferring aspects of the culture belonging to one group to that of another. Over the centuries, translation has played an important role in terms of cultural enrichment. So much so, that it may be said that the inception of modern national literatures, particularly in the case of minority languages, can often be traced back to translations from originals derived from existing and influential literary systems. As a result, complex and dynamic interaction between translated texts and the receiving culture's own literary production has taken place. In instances where the 
minority literature is still young, it leaves itself open to foreign influences and translated literature can thus potentially make an active and extensive contribution to the development of the language and culture (cf. Delisle \& Woodsworth 1995:7-24; 45-54; 159-190).

It should also be noted that discussions in poststructuralist and postcolonial fields have increasingly focused on agency: given that in all instances we have already been formed by the discourses of the age in which we live, how can anyone effect cultural change? The cultural turn in translation studies has become the 'power turn', according to Tymoczko and Gentzler (2002:xvi), with questions of power being brought to the fore in discussions of strategies for translation:

How can a translator effect cultural change?

How can translators bridge cultural gaps?

Under what circumstances do translations have maximum impact?

How does translation relate to cultural dominance, cultural assertion, and cultural resistance?

As part of the basis for ordinary, everyday communication, translation remains an integral component of the colonial power differentials that shaped it in the first place. Hermans (1999:62) points out that language is subjectively coloured and emotionally charged, rather than neutral and impassive. Robinson in turn (1997:31) points out, as set out in (1) below, that translation is of threefold importance:

(1)(a) as a channel of colonisation, parallel to and connected with education and the overt or covert control of markets and institutions;

(b) as a 'lightning-rod' for cultural inequalities persisting after the demise of colonialism; and

(c) as a channel of decolonisation.

Jacquemond (1992:139-158) offers four main hypotheses regarding translational inequalities, as set out in (2):

(2)(a) A dominated culture will invariably translate far more of a hegemonic culture than the latter will of the former.

(b) When a hegemonic culture does translate works produced by the dominated culture, those works will be perceived and presented as difficult, mysterious, inscrutable, esoteric, and as requiring a small cadre of intellectuals to interpret them, while a dominated culture will translate a hegemonic culture's works with a view to easy accessibility for the masses. 
(c) A hegemonic culture will only translate those works by authors in a dominated culture that fit into the former's preconceived notions of the latter.

(d) Authors in a dominated culture striving for a larger audience will tend to write for translation into a hegemonic language, and this will require some degree of compliance with stereotypes.

Unfortunately, these hypotheses do not state how translations are performed, i.e., the macrostructural (global) and microstructural translation strategies (see next section) are not explicated. The analysis of the realisation of these strategies is the objective of this research project. Given the restrictions on space, the focus of this paper will fall mainly on the macrostructural (global) translation strategies.

\section{Analytical framework}

Lambert and Van Gorp (1985:52-53) provide some practical guidelines for the descriptive analysis of translations and their originals. The following guidelines were employed in the analysis:

\subsection{Preliminary data}

As a first step, the researcher/critic is required to collect general information about the translation, gleaned from the title and the title page, as well as information concerning the strategy of the translator(s) in the metatexts (gleaned from sources such as the preface and footnotes). This action supplies the introductory data on the basis of which a provisional hypothesis may be formulated.

\subsection{Macrostructural (global) features}

The second stage provides an opportunity for the analysis of the general, macrostructural (global) features found in the translation. This may include a consideration of the divisions in the text, the titles of the various divisions, the internal structure, comments by the translator(s), and/or other directives and explanations. 


\subsection{Microstructural features}

It is only at the third (micro-level) stage that the selected chapters are considered. A survey thereof probes detail such as the shifts on the phonic, graphic, syntactic, stylistic and elocutionary levels, including the selection of words, dominant grammatical patterns, modality, etc.

\subsection{Systemic context}

In this step of the Lambert and Van Gorp model, all the data from the survey are collected and considered in relation to the system in its entirety. The entire process is viewed in terms of the target cultural system and the place it occupies within this system.

\subsection{The tertium comparationis}

The process of contrasting, i.e. searching for differences, is conducted against a background of sameness. This sameness is referred to as the constant, and the differences as variables. In the theory of contrastive analysis the constant is referred to traditionally as the tertium comparationis. In respect of culture, the source text may be compared to the target text in terms of the cultural dimensions, as set out in Newmark (1988:103):

(3)(a) Ecology: animals, plants, local winds, etc.

(b) Material culture (artefacts): food, clothes, housing, etc.

(c) Social culture: work and leisure.

(d) Organisations, customs, ideas - political, social, legal, religious, etc.

(e) Gestures and habits.

Aspects of culture, such as the above, will then constitute the tertium comparationis.

\section{Analyses of translations}

\subsection{Rehabilitation of the dominated target culture}

Danso (2002) analysed the translation strategies utilised by Rev. J J R Jolobe (1902-1976) in transferring certain cultural properties while translating Rider Haggard's King Solomon's Mines into Xhosa under the title of Imigodi kaKumkani uSolomon (1968).

The novel was written in 1885 by a white male. Henry Rider Haggard (1856-1925) was subjected to the entire spectrum of colonialist and imperialist beliefs of his day. The novelist spent a 
number of years in South Africa, where he held a position in the colonial government. Thus Africa became the setting of his most famous adventure story, King Solomon's Mines. The story, inspired by an interpretation of the Zimbabwe ruins, relates the fictitious adventures of an English explorer among mythical, lost tribes. Rider Haggard's romanticised adventure stories had an informative aim and also ventured to stimulate the interest of the British people in the unknown, with the ultimate aim being the maintenance and expansion of British colonisation and resultant domination in foreign territories. His work is characterised by sentimentalisation and idealisation (of images such as those of 'the African', the child, the woman, the past, and of nature) and a subsequent distortion of reality into the veneration of a martial spirit, virility and an all-pervasive racism and arrogant paternalism (Katz 1987:32-33, 39).

J J R Jolobe's reason for translating King Solomon's Mines into the Xhosa version, Imigodi kaKumkani uSolomon (1968), was the sudden and urgent need for more books in Xhosa. Ironically, this need had arisen as a result of the introduction of Bantu Education in 1953 during the heyday of Apartheid. Jolobe's translation, although close to the source text and accurate in terms of the source text story, was nevertheless by no means a direct transcription of the English text into Xhosa. Black South Africans at the time, especially the youth, were politically conscious and extremely sensitive to the presence of racist language. In order to render this book innocuous, and acceptable in terms of the Xhosa culture, and thus also to the target readership, Jolobe had to expunge large portions of the source text. Thus, for example, he had to remove words reflecting Haggard's overt racist background ('Kaffirs' [p.53], 'boys' [p. 50], 'slaves', 'natives' [p. 41], 'savages' [p.51]). Jolobe substituted these terms with culturally acceptable nouns, thus giving recognition to the inherent humanity of black identity through terms such as: abantu abamnyama (p.11) (black people); abantu abantsundu (p.23) (lit. dark-skinned people) and iinkulelane (p.49) (lit. people who grew up in that place). Superfluous racist and paternalistic stereotypes were left untranslated. Gauton (2000) refers to this practice as the 'rehabilitation' of culture. In this sense, customs were also rehabilitated. The translation turned out to contain linguistic, cultural and textual items that were absent from the source text; perhaps for reasons of clarity, to provide missing links and/or to enhance the quality of the target text (4). 
(4)

ST: The women blessed us (lit. abafazi basisikelela)(p.232)

TT: Abafazi bonabesitshayelela besincoma besisikelela (p.118)

(lit. the women were ululating, complimenting and blessing us).

The wording in the target text evokes a typical manifestation of happiness in the target culture.

There is great disparity between the English and Xhosa cultural kinship systems as illustrated in (5). The kinship terms were also rehabilitated in the target culture:

(5)(a)

ST: I am his uncle (p.88).

TT: Mna ndinguyise omncinci (p.49) (lit. I am his younger father).

(5)(b)

ST: O, my uncle, I am Ignosi (p.117).

TT: Bakokazi, ndingu Ignosi (p.66) (lit. my father's brother, I am Ignosi).

(5)(c)

ST: It is my brother's son (p.117).

TT: Ngunyana womkhuluwa (p.67) (lit. he is my elder brother's son).

$(5)(d)$

ST: Then Ignosi calls Infadoos 'my uncle' (p.117).

TT: Bawomncinci (p.67) (lit. younger father).

$(5)(\mathrm{e})$

ST: Mr Quatermain (p.19).

TT: Mfo ka Quatermain (p.13) (lit. fellow of Quatermain).

The target text's possessive construction places Quatermain closer to his father and to his ancestral family tree than the neutral 'Mr'.

The strategy of rehabilitation employed by Jolobe presents a clear example of the trends followed by translators of colonial texts in negotiating the harsh imperialistic overtones of the source texts. In this way, a palatable and culturally appropriate translation could be fashioned for the target readership, as far as the cultural, historical and political power relations inherent to the source text were concerned. Jolobe's translation strategies are akin to those of the functionalist and culturally-oriented descriptive translation theories which were developed in reaction to linguistic and equivalence-based translation theories. His chosen translation model of cultural compromise ensured that the source text was neither completely acculturated, nor literally translated. As a 
result, Jolobe achieved his initial aim, in terms of the norm of accommodating the linguistic, literary and cultural views of the target readership. Jolobe's translation has been accepted in the literary culture of the target readership because it reads like an original Xhosa novel. The hypothesis, namely that a dominated culture will translate a hegemonic culture's works so as to render them accessible to the masses, is therefore justified by this analysis and it is also confirmed by the analysis of Hlongwane (2000).

\subsection{Subversion of the dominant source culture}

The macrostrategy used for the translation of the American work, Five Foundations for Marriage, into Southern Sotho by M I Mpoba (2001), resulted in the complete acculturation, indigenisation and domestication of the source text in the target culture. All of the American names were substituted with South African ones. The name of the main character, Robert, became Mafotha. The name Salem, associated with a great riverside holiday resort, was translated as Parys, a town in the Free State. Similarly, the name, America, was replaced by Afrika Borwa, while all cultural references were changed to fit the South African context. Statistics and the currency, for example, were adapted. Whereas the process of building an American house was used in the source text as a metaphor for marriage, this image was replaced in the translation by a typical township house. The American concept of a beautiful woman was replaced by the African equivalent.

A further example of the subversion of the dominant culture is evidenced in the utilisation of the mutation strategy. Southern Sotho speakers fail to understand the concept of compromising in terms of meeting halfway; rather they interpret it as abandoning that which one holds dear, i.e. giving up or surrendering to the opposing force. Within African culture the husband must always have his way. Therefore, the translator applied the strategy of mutation by translating compromising with the term to consider.

Another issue to consider was the fact that the concept of a husband and wife who have access to their own separate/private funds is also not yet generally accepted in an African milieu, where the husband is still firmly considered to be the head of the household. Any deviation from the 
accepted status quo would be regarded with suspicion and as a source of mistrust between husband and wife. The husband alone usually decides how money will be spent. Mutation was once again applied in the translation. This time, it is emphasised that both partners should have a say in the spending of financial resources.

Introducing children to matters of sexuality is another matter that is not yet acceptable among an African audience. In this regard, the translator utilised the strategy of generalisation to convey this aspect by means of a phrase couched in neutral terms.

There is also no concept or custom in respect of a honeymoon in the Southern Sotho culture. Here, generalisation was again utilised, through the choice of the Southern Sotho term leqatheng, to indicate a time to be alone together. Leqatheng refers to a house with no inhabitants other than the couple. Although the house is located in close proximity to the main or parental house, the husband and wife would be alone in the house - especially during the night - but, in contrast to honeymooners, would still be going about their daily chores, as is the custom.

\subsection{Maintenance of the dominated source culture by resistance against the dominant target culture}

The novel By die Lêplek van die Leeus (In the Lions' Den) by Louise Prinsloo, is a South African story written for and about South African youth in a modern context and was translated by Nannette Lötter (2001) into English. The original version was recently prescribed for Grade 11 learners in the Limpopo Province, and it is hoped that other provinces will follow suit. The story, written in Afrikaans, concerns a Zulu-speaking girl who leaves her home and family to go to an Afrikaans university. In her new surroundings, she is obliged to accept lodging with a white, Afrikaans-speaking family. The novel exhibits an array of elements derived from various cultures and languages.

An English translation was achieved without downplaying the African culture, while promoting greater understanding among different cultures. Strategies associated with the transfer of culturespecific elements in a translation from Afrikaans into English were employed in such a way as to 
incorporate the cultures of all of the protagonists. The aim was to make the translated text acceptable to a variety of South African cultural groupings by enabling each to identify with the story.

The concept of cultural identities is particularly relevant to the English translation of By die Lêplek van die Leeus. The emphasis in this translation falls on cultural identities: the use of cultural words and concepts and the technique of foreignisation allow the clear demarcation of each cultural group. In other words, the premise was adopted that a cultural gap should not be bridged, but rather be created. The reason for highlighting cultural identities can be seen as the need to promote the understanding of various cultures and to cultivate an appreciation of the unique and unmistakable characteristics of each culture, as well as a realisation that each culture has its own unmistakable characteristics and an equal right to existence as a community.

The macrotextual strategy that was utilised, entailed the retention of as many of the foreign codes as possible (Heylen 1993). The microtextual strategies of transference and domestication/indigenisation were used to achieve this end. Within the framework of postcolonial translation the meanings of most of the transferred cultural words were clarified by their context.

With regard to social culture, the following terms of address were transferred from the source text to the target text:

(6)(a) Zulu: Gog (granny), Malume (uncle), Sangoma (witchdoctor, traditional healer)

(b) Afrikaans: Hottie (name, probably short for Hottentot), Miesies (madam, from 'Mrs'), Ouma (granny), Oom (uncle), Baas (master), Tannie (aunty), Swaer (brother-in-law), Kleinbaas (young master) and Dominee (Reverend).

In respect of material culture, words for food, drink, clothing, medicine and housing, belonging to a particular culture, were transferred:

(7)(a) koeksisters (twisted confectionary, dipped in syrup);

(b) braaivleis (barbecue);

(c) pap (maize-meal porridge);

(d) seshebo (tomato, onion and chilli mixture);

(e) umqombothi (traditional beer, home-brewed);

(f) karos (small blanket made from cured skins); 
(g) kierie (a long stick with a knob at one end, similar to a walking stick - sometimes used, traditionally, for fighting or even hunting);

(h) stoep (verandah);

(i) witdulsies and rooilaventel (traditional home remedies - these are traditionally Afrikaner remedies and serve to underline the culture of Ouma Magrieta).

The foreignisation of a fairly large number of words culminated in a translation in which cultural groupings were clearly defined in keeping with the intention to establish cultural identities and foster an understanding for and with other cultures. Readers of the source text and translation are constantly made aware of their cultural heritage, and they are sensitised to the realities of cultures which differ to a greater or lesser extent from their own. A mutual respect and affection is thus nurtured through such understanding.

\subsection{Enrichment of the dominated target culture}

The Prisoner of Zenda by Anthony Hope was written in 1894 and translated into Xhosa by G B Sinxo in 1958. The research problem to be considered in this instance is how the foreign culture (food, clothes and social customs) is represented in the target text. The hypothesis is that the English material and social culture were transferred to Xhosa, with no attempt at acculturating the original work to the material and social circumstances of the target culture.

The many differences in convention between the Western source and the Xhosa target culture should come as no surprise. These differences are directly related to matters of food, clothing and social customs. For example, in the story the king and his advisers drink wine during dinner. In Xhosa culture it is not customary for people to eat food and drink liquor simultaneously: rather, they would eat first and take beverages afterwards. They would also not drink wine, but umqombothi (African beer) or brandy. A further example can be cited: the king wears canvas shoes and a pair of knickerbockers. This attire would certainly not suit an African king. The African ruler customarily wears izidabane (clothes made from animal skins). According to the source text, the king also wears a uniform. In Xhosa there is no equivalent term for uniform. The term isinxibo senkosi (king's attire) is used as a rule. By the same token, the Xhosa king would call his advisers by their clan names and not by their first names, as is the case in the source text. Also, in the novel, when the king and his advisors fight Duke Michael's people, they use helmets 
for protection. Xhosa men do not protect their heads when fighting, as this is interpreted as a show of cowardice. In fact, the term helmet does not exist in Xhosa. Xhosa men also fight with sticks and spears and not with swords (Mlonyeni 2004:3-4).

It is therefore clear from the above that the cultural system reflected in the source text greatly influenced the translation. What motivated Sinxo to translate in the way that he did? In other words, why was the foreign culture retained in the Xhosa translation? The translator exhibited a need to introduce the source-text cultural system to the target-text system, as both English and Xhosa have a high regard for royal families. The two main strategies used to achieve this objective are illustrated in (8) and (9):

(8) Transference

(a) ST: Zenda (Hope 1894:53)

TT: $\quad$ EZenda (Sinxo 1958: 47)

(b) ST: Cellar (Hope 1894:37)

TT: $\quad$ Isela (Sinxo 1958:23)

(c) ST: Cigarette (Hope 1894:5)

TT: $\quad$ Isigarethi (Sinxo 1958:10), (instead of umdiza).

Transference is the process of transferring a source-language item to a target-language text unchanged; the source-language item then becomes a loan item in the target language (Naudé 2000:18). The implication is that the target culture is thereby enriched.

(9) Omission

ST: $\quad$ I took my dear Michael and kissed him on the cheek (Hope 1894:30).

TT: Deleted.

The source text phrase kissed him on the cheek has been deleted in the target text, because this gesture is offensive in the target culture.

Culture-specific terms unique to the source language have been transferred into the target text, as reflected in (10): 
(10)

(a) ST: Wine (Hope 1894: 18)

TT: $\quad$ Iwayini (Sinxo 1958: 11)

(b) ST: Cigarette (Hope 1894: 17)

TT: $\quad$ Isigalethi (Sinxo 1958:18)

(c) ST: Uniform (Hope 1894: 23)

TT: $\quad$ Iyunifomi (Sinxo 1958: 15)

(d) ST: $\quad$ My Helmet (Hope 1894:25)

TT: $\quad$ Ihelmet yam (Sinxo 1958:16)

(e) ST: Revolver (Hope 1894: 41)

TT: $\quad$ Ivolovolo (Sinxo 1958:18)

(f) ST: $\quad$ Cellar (Hope 1894: 38)

TT: $\quad$ Isela (Sinxo 1958: 23)

The translator has chosen to adhere to the source-text system in an attempt to introduce the source culture's milieu of royal life into the target culture. The source-text material's culturespecific terms, as well as the source-text customs and royal procedures, have been transferred into the target text. In this process, source-text words are transferred to the target text unchanged, and the source-language word becomes a loan word in the target language. This has been done to enrich Xhosa and to introduce the target-text readership to the royal life of the source text. A striking example is the order of the procession of the king, his aides and dignitaries, after the coronation. The king is in the middle, amongst other people, and not in front as would be the case in the target culture. This serves to show that security is highly regarded in the source culture, and even more so for royalty. Such procedures for royalty are nowadays practised in the target culture for the same reason: to ensure the security of the royal family. It should be noted, however, that Sinxo has omitted potentially culturally offensive aspects (for the target culture), as well as those aspects that he feels to be unimportant. As a result, the message has not been distorted.

\subsection{Adaptation of the dominant source culture}

The Southern Sotho-speaking community has proved itself to be an avid religious (Christian) audience. Nonetheless, the supply of religious literature in Southern Sotho, such as in the form of elementary commentaries and lectionaries, books of religious stories for children, and catechisms, is extremely limited in scope and meagre in number. As a result the literary base has proven woefully inadequate in addressing the need for the communication and transfer of 
religious thought. The existing Southern Sotho literature is insufficient for the purpose of giving voice to the moral aspects within the Southern Sotho religious community. In addition, the various modes for communicating religion, such as sermons and Bible study, tend to be received negatively, as being too monotonous. African liturgy emphasises the experiential rather than the cerebral agency for the transfer of the text message. This could be interpreted as a contributing factor to the present stagnation in religious life that is being experienced by the Southern Sotho community.

Most members of this religious community are illiterate. Hence, a new Bible translation into Southern Sotho, or additional religious literature in the traditional mode, will have little or no effect on the present state of affairs. The translator, TJ Makutoane, therefore set out to investigate alternative means by which to convey religious ideas, with preference being given to a participatory mode of communication. One such means ideally suited to predominantly illiterate audiences, ancient or modern, is that of drama. The inclusion of plays in the liturgy has been found to contribute significantly to the reanimation of formal religious experience by means of audience participation. The performance of a religious/moral drama can thus serve as an important ancillary to both formal and informal religious communication, and such performances could contribute to the moral and religious reinvigoration of the Southern Sotho-speaking community.

The fourteenth-century C.E. morality play Everyman was written for the people of its day, and hence reflected a very particular culture, belief system and worldview. This text furthermore expressed the fourteenth-century religious interpretation of the morals and ethics of the ancient Near Eastern worldview on which it was based. At the same time, the twenty-first-century translator recognised that in many respects the Biblical and fourteenth-century audiences shared the circumstances of the present-day Southern Sotho community. Owing to the religious relevance of the play for the present Southern Sotho audience, this drama was translated in such a way as to further enhance its already-perceived relevance to the prospective audience. 
Despite its simplicity, this type of play remains difficult for the twenty-first-century Southern Sotho hearer to follow, as conventions first have to be acquired before understanding can take place. Owing to the play's importance (content) and relevance, certain strategies were put in place to overcome conventional and other difficulties. The strategies emphasised the need for indigenisation in order to optimise understanding. Accordingly, the strategies employed were operative on the macro- as well as the micro-level. Adaptation was used as a macro-strategy to translate Everyman for the prospective audience. According to Newmark (1988:64) adaptation is the 'freest' form of translation available. It is used mainly for plays (comedies) and poetry. The themes, characters, and plots are usually preserved, while the source-language culture is converted to the target-language culture and the text rewritten.

\begin{tabular}{|l|l|}
\hline English & Southern Sotho \\
\hline Everyman & Mothofeela \\
\hline Messenger & Leqosa \\
\hline Death & Lefu \\
\hline Fellowship & Kopano \\
\hline Kindred & Molemo \\
\hline Cousin & Motswala \\
\hline Good deeds & Diketso tse ntle \\
\hline Knowledge & Tsebo \\
\hline Confession & Boipolelo \\
\hline Beauty & Botle \\
\hline Strength & Matla \\
\hline Discretion & Kelello \\
\hline Five wits & Tsebohlano \\
\hline Angel & Lengeloi \\
\hline Doctor & Ngaka \\
\hline
\end{tabular}

\section{Conclusion}

The realisation of postcolonial translation studies in the mid-1990s led to the understanding that translations could benefit the culture of the colonised at the expense of the culture of the coloniser/imperialist. This contribution has ventured to indicate, through a translation-critical 
analysis, how, in South African translations, by means of certain techniques and strategies, the dominated target culture can be rehabilitated; how the dominant source culture is sometimes subverted; how the dominant target culture can be resisted by maintaining the dominated source culture; and how the dominated culture can be enriched (12).

HEGEMONIC SC ---> DOMINATED TC

Subverted

Adapted

rehabilitated

enriched

DOMINATED SC -----> HEGEMONIC TC

Maintained

resisted

One relationship is still under investigation and has not received attention in this paper, namely the question of how the dominated culture is translated for the global market (13):

(13)

DOMINATED SC ----> HEGEMONIC TC

Globalised ---> dominated SC ---> English

English ----> dominated TC

In all instances the translator operates in the language of the dominated culture. Readers of the source text and translation are aware of their cultural heritage and they are brought into contact with the realities of cultures differing greatly from their own. Mutual respect and affection are promoted through understanding.

* I would like to thank two anonymous SPIL-reviewers for their comments on a previous draft of this paper. 


\section{References}

Bambelo, L. 2003. A C Jordan's Ingqumbo Yeminyanya in English. A descriptive study of the translation strategies in The Wrath of the Ancestors. Unpublished MA minithesis, University of the Free State, Bloemfontein.

Bassnett, S. and A. Lefevere. 1990. Introduction. In S. Bassnett and A. Lefevere (eds.) Translation, history and culture. London: Pinter.

Bassnett, S. and H. Trivedi. 1999. Introduction. In S. Bassnett and H. Trivedi (eds.) Postcolonial translation: theory and practice. London: Routledge.

Bassnett-McGuire, S. 1991 [1980]. Translation studies. $2^{\text {nd }}$ revised edition. London: Methuen.

Beukes, A. M. 1994. Vertaling in Suid-Afrika by 'n kruispad. Suid-Afrikaanse Tydskrif vir Taalkunde 12(4): 101-107.

Crystal, D. 2003 [1997]. English as global language. $2^{\text {nd }}$ edition. Cambridge: Cambridge University Press.

Danso, N. 2002. Trends in colonial translation. Henry Rider Haggard's King Solomon's Mines in Xhosa. Unpublished MA minithesis, University of the Free State, Bloemfontein.

Delisle, J. and J. Woodsworth. 1995. Translators through history. Amsterdam: John Benjamins.

Derrida, J. 2001. What is a "relevant" translation? Critical Inquiry 27 (2): 174-200.

Dimitriu, I. 2002. Translation, diversity and power. An introduction. Current Writing 14(2): ixiv. 
Even-Zohar, I. 1990. Polysystem theory. Poetics Today 11(1): 45-51.

Fairclough, N. L. 1989. Language and power. London \& New York: Longman.

Fawcett, P. 1997. Translation and language. Linguistic theories explained. Manchester, UK: St Jerome.

Gauton, R. 2000. The transfer and 'rehabilitation' of culture in the Zulu translation of H Rider Haggard's 'Nada the Lily'. Language Matters 31: 103-129.

Geldenhuys, C. 2004. Translation for the global market. A P Brink's Donkermaan in English and Dutch. A corpus-based analysis. Unpublished MA minithesis, University of the Free State, Bloemfontein.

Hermans, T. 1985. Translation studies and a new paradigm. In T. Hermans (ed.) The manipulation of literature: studies in literary translation. London: Croom Helm.

Hermans, T. 1999. Translation in systems. Descriptive and system-oriented approaches explained. Manchester, UK: St Jerome.

Heylen, R. 1993. Translation, poetics and the stage: six French 'hamlets'. London: Routledge.

Hlongwane, J. B. 2000. Henry Rider Haggard's Nada the Lily in Zulu: an analysis of some translation shifts within descriptive translation studies. Unpublished MA minithesis, University of the Free State, Bloemfontein.

Jacquemond, R. 1992. Translation and cultural hegemony. The case of French-Arabic translation. In L. Venuti (ed.) Rethinking translation. London: Routledge. 
Katan, D. 1999. Translating cultures. An introduction for translators, interpreters and mediators. Manchester: St Jerome.

Katz, W. R. 1987. Rider Haggard and the fiction of empire. A critical study of British imperial fiction. Cambridge: Cambridge University Press.

Kress, G. and R. Hodge. 1979. Language as ideology. London: Routledge \& Kegan Paul.

Kruger, A. 2000. Introduction: Translation studies in South Africa at the turn of the $21^{\text {st }}$ Century. Language Matters 31: 3-12.

Lambert, J. and H. Van Gorp. 1985. On describing translations. In T. Hermans (ed.) The manipulation of literature: studies in literary translation. London: Croom Helm.

Leeto, K. M. forthcoming. The role of the female body in Henry Rider Haggard's King Solomon's Mines into Southern Sotho. Unpublished MA minithesis, University of the Free State, Bloemfontein.

Lötter, N. J. 2001. Translating culture-specific elements in a South African novel for young adults 'By die Lêplek van die Leeus'. An experiment in postcolonial translation studies. Unpublished MA minithesis, University of the Free State, Bloemfontein.

Makutoane, T. J. 2003. A functionalist translation of the morality play Everyman into Southern Sotho. Unpublished MA minithesis, University of the Free State, Bloemfontein.

Mlonyeni, S. G. 2003. Enriching Xhosa culture. The transference of social and material culture in the Xhosa translation of The Prisoner Of Zenda. Unpublished MA minithesis, University of the Free State, Bloemfontein. 
Mpoba, M. I. 2001. A functionalist approach towards translating premarital counselling literature into Southern Sotho. Unpublished MA minithesis, University of the Free State, Bloemfontein.

Munday, J. 2001. Introducing translation studies. Theories and applications. Routledge: London \& New York.

Mweza, Y. forthcoming. $R$ L Peteni's translation in Xhosa of his novel Hill of Fools. Unpublished MA minithesis, University of the Free State, Bloemfontein.

Naudé, J. A. 2000. Review of C. Schäffner, 2000. Translation in the global village. Clevedon: Multilingual Matters. Linguist List 11-2325.

Naudé, J. A. 2002. An overview of recent developments in translation studies with special reference to the implications for Bible translation. Acta Theologica Supplementum 2: 44-69.

Naudé, J. A. 2005. The cultural turn in South African translation. Rehabilitation, subversion and resistance. Acta Academica 37(1): 22-55.

Newmark, P. 1988. A textbook of translation. London: Pergamon.

Nord, C. 1991. Text analysis in translation: theory, methodology, and didactic application of a model for translation-oriented text analysis. Amsterdam: Rodopi.

Nord, C. 1997. Translating as a purposeful activity: functionalist approaches explained. Manchester, U.K.: St Jerome Publishers.

Reiss, K. and H. J. \& Vermeer. 1984. Grundlegung einer allgemeinen translationstheorie. Tübingen: Niemeyer. 
Robinson, D. 1997. Translation and empire. Postcolonial theories explained. Manchester, U.K.: St Jerome Publishers.

Snell-Hornby, M. 1990. Linguistic transcoding or cultural transfer. A critique of translation theory in Germany. In S. Bassnett and A. Lefevere (eds.) Translation, history and culture, 79-86. London: Pinter.

Snell-Hornby, M. 2000. Communicating in the global village: On language, translation and cultural identity. In C. Schäffner (ed.) 2000. Translation in the global village. Clevedon: Multilingual Matters.

Toury, G. 1978/2000. The nature and role of norms in literary translation. In: L. Venuti (ed) 2000. The Translation Studies Reader, 198-211. Routledge: London.

Toury, G. 1995. Descriptive translation studies and beyond. Amsterdam: John Benjamins.

Tymoczko, M. and E. Gentzler. 2002. Introduction. In M. Tymoczko and E. Gentzler (eds.) Translation and power. Amherst \& Boston: University of Massachusetts Press.

Venuti, L. 1995. The translator's invisibility: a history of translation. London: Routledge.

Venuti, L 2000. Introduction. In L. Venuti (ed.) The Translation studies reader. Routledge: London.

Walker, A.K., A. Kruger and I.C. Andrews. 1995. Translation as transformation: a process of linguistic and cultural adaptation. South African Journal of Linguistics, Supplement 26: 99116.

Wallmach, K. 2000. 'Get them lost just as in the narrow streets of the casbah': metaphors of resistance and subversion in translation. Hermeneus 2: 235-258. 